\title{
Quantitative and Qualitative Composition of Bacterial Communities of Malting Barley Grain and Malt during Long-Term Storage
}

\author{
Soňa Felšöciová ${ }^{1}$, Przemysław Łukasz Kowalczewski ${ }^{2}$ (), Tomáš Krajčovič ${ }^{3}$, Štefan Dráb ${ }^{3}$ and \\ Miroslava Kačániová 4,5,*(D) \\ 1 Department of Microbiology, Faculty of Biotechnology and Food Sciences, Slovak University of Agriculture, \\ Tr. A. Hlinku 2, 94976 Nitra, Slovakia; sona.felsociova@uniag.sk \\ 2 Department of Food Technology of Plant Origin, Poznań University of Life Sciences, 31 Wojska Polskiego St., \\ 60-624 Poznań, Poland; przemyslaw.kowalczewski@up.poznan.pl \\ 3 Heineken Slovakia Sladovne, a.s., Novozámocká 232/2, 94701 Hurbanovo, Slovakia; \\ krajcovic.thomas@googlemail.com (T.K.); drab.stefan@gmail.com (Š.D.) \\ 4 Department of Fruit Science, Viticulture and Enology, Faculty of Horticulture and Landscape Engineering, \\ Slovak University of Agriculture, Tr. A. Hlinku 2, 94976 Nitra, Slovakia \\ 5 Department of Bioenergetics, Food Analysis and Microbiology, Institute of Food Technology and Nutrition, \\ University of Rzeszow, Cwiklinskiej 1, 35-601 Rzeszow, Poland \\ * Correspondence: miroslava.kacaniova@gmail.com; Tel.: +421-37-641-715
}

Received: 16 August 2020; Accepted: 28 August 2020; Published: 1 September 2020

check for updates

\begin{abstract}
In the grain samples of three malting barley varieties harvested in 2016, and in the malt made from them, we observed microbial changes during storage. Analyses were performed after $0,3,6$, and 9 months of storage in floor warehouses and silos. We monitored microbial changes based on the quantitative determination of microorganisms using a plate dilution method and qualitative determination of microorganisms, where we identified a particular species of bacteria using the MALDI-TOF MS Biotyper instrument (Bruker Daltonics, Bremen, Germany). Based on the quantitative determination of microorganisms, we found that the total plate counts of microorganisms was higher in malts than in barley grains. The storage period had the greatest impact on the number of coliform bacteria, which gradually increased with the growing months in storage. The number of lactic acid bacteria in barley grains with the growing months in storage and malt produced from them decreased slightly, and the content of the sporulating bacteria in all the samples fluctuated slightly. Differences in the numbers of observed microorganisms were negligible during storage between floor warehouses and silos. In the samples of barleys, the most commonly identified species were Pantoea agglomerans, which was also present in malt samples but did not belong to the dominant species. A diverse species representation appeared in the samples, whereas predominating species belonged to the Enterobacteriaceae family.
\end{abstract}

Keywords: malting barley; bacteria; mass spectrometry; storage

\section{Introduction}

Barley is not only an important feed crop, but it is also the predominant raw material for the production of malt for brewing purposes. Although barley physiology is of utmost importance for malt quality, the impact on malt quality of the natural microbial population throughout the complete production chain should not be ignored [1]. Many intrinsic and extrinsic factors, including plant variety, climate, soil type, agricultural practices, storage, and transport influence the diversity and structure of the microbial community present $n$ barley grains [2-4]. 
The indigenous microbial community of barley harbors a wide range of microorganisms, including numerous species of Gram-negative and Gram-positive bacteria, yeasts, and filamentous fungi [3], and is often associated with unwanted trends such as variability in malt batches, grain dormancy, undesirable aromas, and interference with barley respiration [5] or by producing mycotoxins [6].

Bacteria numerically dominate in the culturable microbial community of pre-harvest barley [2]. Approximately 10 million bacteria are frequently detected in one gram of barley. The most common and abundant bacterial species during growth is Erwinia herbicola (now Pantoea agglomerans) [3]. The composition of the microbial population of barley changes during storage depending on the initial microflora composition, the storage time, and the environmental conditions [1]. While storing and transporting grain, its microbiological quality indicators play a very important role. Grain seeded with various microorganisms quickly loses its functional and technological properties, which negatively affects the quality of beer produced from it [7].

Following harvest, barley may be stored for a time prior to malting to overcome dormancy. During this time, microbes continue to grow on and interact with the living grain, and conditions must be monitored carefully to minimize microbial growth [8], which can be extremely detrimental to beer quality [9]. Between the critical factors which affect the development of saprophytic microorganisms in the grain mass are the average moisture content of the grain mass, the moisture content of the individual components of the grain mass (humidity of the main grain, impurities, and air of intergranular spaces), the temperature of the grain mass, the degree of aeration, the integrity, and the condition of the integumentary grain tissues, its vital functions, the amount, and species composition of impurities are also essential. If the moisture content of the grain mass of any culture is significantly higher than critical, then in the presence of other favorable conditions (mainly a certain temperature), microorganisms develop rapidly, which are accompanied by noticeable changes in the quality of the grain. The intensity of the process is explained by the presence in the microcapillaries of the shells of the grain of a significant amount of water used by microorganisms. Thus, humidity is one of the important indicators of quality, which affects the preservation of the functional and technological properties of malting barley during storage [7]. In general, bacteria do not grow well during good storage of grains since they are less xerophilic than yeasts and fungi [10]. Spore-forming bacterial species survive better during storage [11].

Malt has a great effect on the brewing performance and on the characteristics of the final beer. The safety and quality of the final beer product depends not only on the fermentation process, but also on the quality of the raw materials used [12]. The most important microbial genera found in malt are from Gram-negative bacteria Clavibacter, Enterobacter, Erwinia, Escherichia, Flavobacterium, Pseudomonas, and form gram positive bacteria Actinomyces, Arthrobacter, Bacillus, Lactobacillus, Leuconostoc, Micrococcus, and Pediococcus [13]. Lactic acid bacteria (LAB) contribute to the flavor, nutritional value, and structure of the products. These microbes can also enhance microbial stability by the production of various organic acids, such as acetic acid and lactic acid that cause a decrease in $\mathrm{pH}$ [14]. LAB can have an active role in detoxifying infected grains through absorbing mycotoxins by the bacterial cell structure or metabolic biodegradation [6,15]. The presence of enterobacteria in the sample (water, wort, yeast, beer) indicates a reduced hygienic level of the beer brewing process [16]. They can compete with the brewer's yeasts and reduce their growth [9]. The presence of enterobacteria in the fermented wort is associated with multiple sensory defects of the finished beer, which can have sweet, honey, fruity to vegetable, and fecal character. The contamination of wort with enterobacteria can also lead to an increased concentration of biogenic amines in beer [17]. However, most enterobacteria are inhibited by ethanol and acidic $\mathrm{pH}$, so they are not able to survive later phases of the main fermentation and are not transferred into the finished beer [9].

The aims of this study were: (i) to observe the microbial changes in barley grain during storage and malt made from it and (ii) to identify the bacteria isolates according to the MALDI-TOF MS Biotyper. 


\section{Materials and Methods}

\subsection{Samples}

Contamination of barley grains with microorganisms during different periods of storage was investigated from 2018 to 2019. Two-row spring malting barley varieties, Laudis and Kangoo, grown in the Levice region, and two-row winter malting barley variety Wintmalt grown in region Zlaté Moravce in the Slovak Republic, were studied.

Laudis-a variety registered in the Slovak Republic in 2012, malting quality index (MQI) 8 (8.5), (variety recommended for export malts production).

Kangoo-variety registered in 2009, MQI 6 (6.4).

Wintmalt-a variety registered in 2011, it achieved the point evaluation 3 (3.2).

There were two types of tested storage-floor warehouse and grain silo. In both store types, we stored $5 \mathrm{~kg}$ of grain in permeate jute bags that were thrown into the pile of barley. The storage temperature was from $10{ }^{\circ} \mathrm{C}$ to $20{ }^{\circ} \mathrm{C}$. The analyses were performed after $0,3,6$, and 9 months of storage in Maltery Heineken Slovensko Sladovne in Hurbanovo, Slovak Republic. A total of 57 samples of barley and 57 samples of malt were evaluated.

\subsection{Micro-Malting Procedure}

After completing dormancy, the above-mentioned barley varieties were malted in a malting plant laboratory four times, from barley (zero weeks, $1000 \mathrm{~g}$ ), three months, six months, and nine months after start of the storage trial. Barley samples were micromalted in the AgroBioTech Research Center of the Slovak University of Agriculture in Nitra.

The technology of laboratory malting:

Samples were micromalted in laboratory micromalting plant, divided into 3 separate units:

Steeping, germination, and kilning box:

Steeping-1st day water for $5 \mathrm{~h}$, 2nd day water for $4 \mathrm{~h}$, full steeped on water content $45.5 \%$. Between the two water phases, air rests were performed, where barley samples were aerated with fresh air in the steeping box, according to a standard program.

Germination-temperature $14.5{ }^{\circ} \mathrm{C}$, total time of steeping and germination was six days. Germination was performed at a malt temperature of $15-16{ }^{\circ} \mathrm{C}$, and proceeded at continuous aerating with fresh conditioned air.

The kilning process was performed on an electrically heated one-floor kiln, with a gentle and gradual increase in temperature up to the kilning temperature of $80^{\circ} \mathrm{C}$ for $4 \mathrm{~h}$.

\subsection{Chemical Analyses}

Barley and malt analyses were carried out according to the European Brewery Convention methodology [18], using the following methods:

1. Barley
(a) Moisture content $=$ EBC 2010-3.2
(b) Protein content = EBC 2010-3.3.1
(c) Starch content = EBC 2010-3.13
(d) Germination capacity = EBC 2010-3.5.2

2. Malt
(a) Moisture content $=$ EBC 2010-4.2
(b) Protein content $=$ EBC 2010-4.3.1
(c) $\quad$ Extract content $=$ EBC 2010-4.5.1
(d) $\quad$ Friability $=$ EBC 2010—4.15 


\subsection{Microbiological Analyses}

Dilution plating (surface spread method) was used for the quantitative and qualitative microbiological analyses of the total plate count of microorganisms, sporulating, coliform, and lactic acid bacteria in barley and final malt. Ten grams of each milled grain sample was homogenized for $30 \mathrm{~min}$ in $90 \mathrm{~mL}$ of physiological solution $(0.89 \%)$. Serial decimal dilutions up to $10^{-6}$ were made and aliquoted from each dilution, and were inoculated in triplicates onto Petri dishes with several selective media (Table 1). For the determination of sporulating bacteria, the grain solution was subjected to a heat shock at $80^{\circ} \mathrm{C}$ for $10 \mathrm{~min}$ prior to inoculation. Plate Count Agar (PCA, Oxoid, Basingstoke, UK) medium for total plate count of microorganisms and sporulating bacteria, Violet red bile lactose agar (VRBL, Oxoid, Basingstoke, UK) for coliform bacteria, and De Man, Rogosa, and Sharpe agar (MRS, Oxoid, Basingstoke, UK) lactic acid bacteria were used. The dishes were kept in thermostat in aerobic conditions except for LAB (microaerophilically). After incubation, the number of microorganisms in $1 \mathrm{~g}$ of the sample was calculated and expressed in CFU/g.

Table 1. Characteristics of the methods used.

\begin{tabular}{cccccc}
\hline Microorganisms & $\begin{array}{c}\text { Dilution of } \\
\text { Samples }\end{array}$ & $\begin{array}{c}\text { Agar } \\
\text { Medium }\end{array}$ & $\begin{array}{c}\text { Inoculation } \\
(\mathbf{m L})\end{array}$ & $\begin{array}{c}\text { Temperature } \\
\left({ }^{\circ} \mathbf{C}\right)\end{array}$ & $\begin{array}{c}\text { Incubation } \\
\text { Time (hours) }\end{array}$ \\
\hline $\begin{array}{c}\text { Total plate } \\
\text { count }\end{array}$ & $\begin{array}{c}\text { Malt } 10^{-5}, 10^{-6} \\
\text { Barley } 10^{-3}, 10^{-4}\end{array}$ & PCA & 1 & 30 & $48-72$ \\
Coliform & $10^{-3}, 10^{-4}$ & VRBL & 0.1 & 37 & $24-48$ \\
Sporulating & $10^{-1}, 10^{-2}$ & PCA & 1 & 30 & $24-48$ \\
LAB & $10^{-1}, 10^{-2}$ & MRS & 0.1 & 30 & $48-72$ \\
\hline
\end{tabular}

Legend: PCA—Plate Count Agar, VRBL—Violet Red Bile Lactose Agar, MRS—De Man, Rogosa and Sharpe agar, LAB-Lactic acid bacteria.

\subsection{Mass Spectrometry Identification of Isolates}

Qualitative determination of microorganisms we identified by using the device MALDI-TOF Mass Spectrometry (Bruker Daltonics, Bremen, Germany). The isolates were subcultured on Tryptone soya agar (TSA, Oxoid, Basingstoke, UK) for total plate count, sporulating bacteria (at $30^{\circ} \mathrm{C}$ ), and coliform bacteria/at $37^{\circ} \mathrm{C}$ ), TSA $90 \%$ with MRS $10 \%$ for lactic acid bacteria at $30^{\circ} \mathrm{C}$ for $24 \mathrm{~h}$. the criteria for reliable identification were a score of $\geq 2.0$ at the species level [19].

\subsection{Statistical Analyses}

The experiments of antioxidant activity and total polyphenol content were carried out in triplicate, and the results were compared by one-way ANOVA and Tukey's test. A difference was considered statistically significant if $p<0.05$.

\section{Results and Discussion}

The results of barleys' basic chemical analyses are in Table 2, and the microbial analyses are in Table 3. The results indicate that bacterial contamination of barley grains before and during storage may be diverse and change during the storage. It has been observed that time and storage of barley samples had an influence on bacterial load. Analysis of microbiological contamination of barley showed that the Wintmalt barley variety had content of coliform as well as lactic acid bacteria, and sporulating bacteria decreased in comparison with ones of Laudis and Kangoo varieties. In Laudis, Kangoo, and Wintmalt barley varieties coliform content increased with storage time. Samples stored in the floor warehouse were contaminated with coliform bacteria more than the samples stored in the grain storage silo. On the other hand, samples were less affected with lactic acid bacteria and their amount decreased after three months of storage in both types of storage. The less increase of sporulating bacteria was detected during the three and six months of storage but in barley Kangoo and Wintmalt, they decreased from nine months' storage. The initial total plate count on barley had the 
highest counts compared to other monitored groups of bacteria, and the storage time had not activated their growth yet. After nine months' storage content of total plate count in barley Laudis, Kangoo, and Wintmalt decreased in both types of storage.

Table 2. Barley basic chemical properties.

\begin{tabular}{|c|c|c|c|c|c|}
\hline $\begin{array}{l}\text { Time of } \\
\text { Storage }\end{array}$ & Varieties & $\begin{array}{c}\text { Moisture } \\
\text { Content [\%] }\end{array}$ & $\begin{array}{c}\text { Protein } \\
\text { Content [\%] }\end{array}$ & $\begin{array}{c}\text { Starch Content } \\
{[\%]}\end{array}$ & $\begin{array}{l}\text { Germination } \\
\text { Capacity [\%] }\end{array}$ \\
\hline \multirow{3}{*}{0.} & Laudis & 11.63 & 11.12 & 63.03 & 95.8 \\
\hline & Kangoo & 11.72 & 11.65 & 62.88 & 98.5 \\
\hline & Wintmalt & 11.54 & 10.57 & 64.53 & 97.0 \\
\hline \multicolumn{6}{|c|}{ Grain silo } \\
\hline \multirow{3}{*}{ 3. months } & Laudis & 12.40 & 11.15 & 63.01 & 93.5 \\
\hline & Kangoo & 12.54 & 11.78 & 62.72 & 98.3 \\
\hline & Wintmalt & 12.74 & 10.82 & 64.14 & 99.0 \\
\hline \multirow{3}{*}{ 6. months } & Laudis & 12.83 & 11.27 & 62.76 & 90.5 \\
\hline & Kangoo & 13.56 & 11.51 & 62.83 & 98.8 \\
\hline & Wintmalt & 12.66 & 10.58 & 64.07 & 98.0 \\
\hline \multirow{3}{*}{ 9. months } & Laudis & 12.90 & 11.20 & 62.85 & 90.0 \\
\hline & Kangoo & 13.82 & 11.60 & 62.75 & 98.2 \\
\hline & Wintmalt & 12.82 & 10.70 & 64.32 & 98.0 \\
\hline \multicolumn{6}{|c|}{ Floor warehouse } \\
\hline \multirow{3}{*}{ 3. months } & Laudis & 12.64 & 11.29 & 62.78 & 92.8 \\
\hline & Kangoo & 12.65 & 11.64 & 63.11 & 98.0 \\
\hline & Wintmalt & 12.58 & 10.94 & 63.73 & 98.3 \\
\hline \multirow{3}{*}{ 6. months } & Laudis & 13.30 & 11.36 & 62.76 & 90.8 \\
\hline & Kangoo & 13.37 & 11.62 & 62.76 & 99.3 \\
\hline & Wintmalt & 13.30 & 10.53 & 64.29 & 98.5 \\
\hline \multirow{3}{*}{ 9. months } & Laudis & 13.21 & 11.27 & 62.72 & 90.2 \\
\hline & Kangoo & 13.48 & 11.68 & 63.02 & 99.0 \\
\hline & Wintmalt & 13.07 & 10.61 & 64.15 & 98.0 \\
\hline
\end{tabular}

Table 3. Quantitative and qualitative composition of various groups of microorganisms from three varieties of barley, depending on the time and type of storage.

\begin{tabular}{|c|c|c|c|c|c|c|}
\hline $\begin{array}{l}\text { Time of } \\
\text { Storage }\end{array}$ & Varieties & $\begin{array}{c}\text { TPC } \\
\log \mathrm{cfu} / \mathrm{g}\end{array}$ & $\begin{array}{c}\text { Coli } \\
\log \mathrm{cfu} / \mathrm{g}\end{array}$ & $\begin{array}{c}\text { LAB } \\
\log \mathrm{cfu} / \mathrm{g}\end{array}$ & $\begin{array}{c}\text { Spor } \\
\log \mathrm{cfu} / \mathrm{g}\end{array}$ & Species \\
\hline \multirow{3}{*}{0.} & Laudis & $5.00 \pm 0.04$ & $3.15 \pm 0.16$ & $3.08 \pm 0.06$ & $1.26 \pm 0.06$ & \multirow{3}{*}{$\begin{array}{l}\text { Pantoea agglomerans } \\
\text { Bacillus altitudinis, } \\
\text { Pantoea agglomerans } \\
\text { Pantoea agglomerans }\end{array}$} \\
\hline & Kangoo & $5.23 \pm 0.09$ & $2.26 \pm 0.02$ & $2.36 \pm 0.14$ & $1.36 \pm 0.08$ & \\
\hline & Wintmalt & $5.84 \pm 0.08$ & $1.11 \pm 0.04$ & $1.30 \pm 0.05$ & $1.00 \pm 0.01$ & \\
\hline \multicolumn{7}{|c|}{ Granaries/storage silo } \\
\hline \multirow{3}{*}{ 3. months } & Laudis & $6.04 \pm 0.01$ & $3.80 \pm 0.09$ & $1.00 \pm 0.10$ & $1.43 \pm 0.02$ & \multirow{3}{*}{$\begin{array}{l}\text { Pantoea agglomerans } \\
\text { Kosakonia cowanii, } \\
\text { Bacillus altitudinis, } \\
\text { Pantoea agglomerans } \\
\text { Pantoea agglomerans }\end{array}$} \\
\hline & Kangoo & $6.28 \pm 0.04$ & $3.60 \pm 0.03$ & $1.00 \pm 0.08$ & $2.40 \pm 0.06$ & \\
\hline & Wintmalt & $6.38 \pm 0.08$ & $3.54 \pm 0.07$ & $1.00 \pm 0.05$ & $2.00 \pm 0.01$ & \\
\hline \multirow{3}{*}{ 6. months } & Laudis & $7.28 \pm 0.08$ & $3.97 \pm 0.03$ & $1.00 \pm 0.02$ & $1.86 \pm 0.10$ & Pantoea agglomerans \\
\hline & Kangoo & $6.36 \pm 0.07$ & $4.71 \pm 0.03$ & $1.36 \pm 0.04$ & $2.15 \pm 0.07$ & Pantoea agglomerans \\
\hline & Wintmalt & $6.28 \pm 0.03$ & $3.65 \pm 0.07$ & $1.00 \pm 0.14$ & $2.11 \pm 0.12$ & Pantoea agglomerans \\
\hline \multirow{3}{*}{ 9. months } & Laudis & $6.23 \pm 0.08$ & $5.26 \pm 0.11$ & $1.30 \pm 0.06$ & $1.83 \pm 0.10$ & Pantoea agglomerans \\
\hline & Kangoo & $6.00 \pm 0.02$ & $5.69 \pm 0.09$ & $1.00 \pm 0.10$ & $1.77 \pm 0.06$ & Pantoea agglomerans \\
\hline & Wintmalt & $5.34 \pm 0.06$ & $4.93 \pm 0.07$ & $1.11 \pm 0.09$ & $2.11 \pm 0.09$ & Pantoea agglomerans \\
\hline
\end{tabular}


Table 3. Cont.

\begin{tabular}{|c|c|c|c|c|c|c|}
\hline $\begin{array}{l}\text { Time of } \\
\text { Storage }\end{array}$ & Varieties & $\begin{array}{c}\text { TPC } \\
\log \mathrm{cfu} / \mathrm{g}\end{array}$ & $\begin{array}{c}\text { Coli } \\
\log \mathrm{cfu} / \mathrm{g}\end{array}$ & $\begin{array}{c}\text { LAB } \\
\log \mathrm{cfu} / \mathrm{g}\end{array}$ & $\begin{array}{c}\text { Spor } \\
\log \mathrm{cfu} / \mathrm{g}\end{array}$ & Species \\
\hline \multicolumn{7}{|c|}{ Floor warehouse } \\
\hline \multirow[t]{3}{*}{ 3. months } & Laudis & $5.92 \pm 0.07$ & $4.00 \pm 0.06$ & $1.00 \pm 0.05$ & $2.11 \pm 0.04$ & $\begin{array}{c}\text { Pseudomonas poae, } \\
\text { Ps. libanensis, } \\
\text { Ps. synxantha, Pantoea } \\
\text { agglomerans }\end{array}$ \\
\hline & Kangoo & $6.30 \pm 0.07$ & $4.18 \pm 0.07$ & $1.00 \pm 0.05$ & $2.34 \pm 0.03$ & Pantoea agglomerans \\
\hline & Wintmalt & $6.15 \pm 0.06$ & $4.04 \pm 0.07$ & $1.36 \pm 0.06$ & $1.56 \pm 0.08$ & Pantoea agglomerans \\
\hline \multirow{3}{*}{ 6. months } & Laudis & $6.23 \pm 0.06$ & $4.93 \pm 0.07$ & $1.00 \pm 0.09$ & $1.43 \pm 0.13$ & Pantoea agglomerans \\
\hline & Kangoo & $6.30 \pm 0.03$ & $5.08 \pm 0.10$ & $1.43 \pm 0.06$ & $1.56 \pm 0.14$ & Pantoea agglomerans \\
\hline & Wintmalt & $6.32 \pm 0.08$ & $3.81 \pm 0.05$ & $1.36 \pm 0.07$ & $1.26 \pm 0.13$ & $\begin{array}{c}\text { Pantoea agglomerans, } \\
\text { Staphylococcus } \\
\text { haemolyticus }\end{array}$ \\
\hline \multirow{3}{*}{ 9. months } & Laudis & $6.04 \pm 0.07$ & $5.69 \pm 0.07$ & $1.00 \pm 0.07$ & $2.67 \pm 0.06$ & Pantoea agglomerans \\
\hline & Kangoo & $6.11 \pm 0.06$ & $5.69 \pm 0.11$ & $1.00 \pm 0.08$ & $1.00 \pm 0.05$ & Pantoea agglomerans \\
\hline & Wintmalt & $6.04 \pm 0.06$ & $5.23 \pm 0.14$ & $1.00 \pm 0.07$ & $1.74 \pm 0.09$ & Pantoea agglomerans \\
\hline
\end{tabular}

Legend: TPC—-total plate count of microorganisms, Coli-coliform bacteria, LAB-lactic acid bacteria, Spor-sporulating bacteria.

Many lactic acid bacteria are considered to be spoilage organisms in the brewing process. However, we found that on the dry-stored barley, the level of lactic acid bacteria was relatively low, with Gram-negative coliforms predominant, which confirms the results of O'Sullivan et al. [20].

Pantoea agglomerans (formerly called Erwinia herbicola) was isolated in barley before storage. According to Flannigan [3], the predominant bacterial species on preharvest barley was Pantoea agglomerans and Xanthomonas campestris. The occurrence of Pantoea agglomerans in our sample was generally the highest. In dry-stored barley for malting, other bacteria, such as pseudomonads, micrococci, and Bacillus spp. were introduced [3]. In our cases, the remaining genera were detected less: Bacillus altitudinis, Kosakonia cowanii, Pseudomonas libanensis, Pseudomonas poae, Pseudomonas synxantha, and Staphylococcus haemolyticus. Petters et al. [11] mentioned that other bacterial species commonly occurring on dry-stored barley included Alcaligenes sp., Arthrobacter globiformis, Clavibacter iranicum, Lactobacillus spp., and Pseudomonas fluorescens.

Bacteria are predominant in a total count of microorganisms in healthy barley [21]. The presence of the genus Bacillus has also been proved in stored barley, which was intended for malting. Therefore, it is assumed that the genus Bacillus is also present on barley before harvesting [21].

The number of bacteria in barley during storage was higher and the following bacteria were isolated: Bacillus altitudinis, Kosakonia cowanii, Pseudomonas libanensis, Pseudomonas poae, Pseudomonas synxantha, and Staphylococcus haemolyticus. Strains of Pantoea agglomerans formed a dominant part of bacterial isolates from barley. A total of 333 isolates from barley were identified (Figure 1). All isolates were from five genera and four families.

When analyzing the statistical differences among microorganisms found in barley/grain depending on the time of storage (Table 4), most of them were statistically significant at the level of $p<0.05$. All of the three analyzed varieties have the same pattern with the following exceptions-no significant difference was found in the case of Wintmalt/grain variety and some of its time counts of LAB and Spor. When analyzing the barley/floor warehouse, the results were more variable. 
Table 4. $p$-values among analyzed barley depending on the time and type of storage of the three varieties of barley $(p<0.05)$.

\begin{tabular}{|c|c|c|c|c|c|c|c|c|c|c|c|c|}
\hline $\begin{array}{l}\text { Variety/Microorganism } \\
\text { Groups }\end{array}$ & & TPC & & & COLI & & & LAB & & & Spor & \\
\hline \multicolumn{13}{|c|}{ Grain } \\
\hline Laudis & 3 & 6 & 9 & 3 & 6 & 9 & 3 & 6 & 9 & 3 & 6 & 9 \\
\hline 0 & $1.978 \times 10^{-6}$ & $1.335 \times 10^{-6}$ & $1.649 \times 10^{-5}$ & 0.004 & 0.001 & $5.034 \times 10^{-5}$ & $5.153 \times 10^{-6}$ & $3.851 \times 10^{-7}$ & $3.153 \times 10^{-6}$ & 0.010 & 0.001 & 0.001 \\
\hline 3 & $\mathrm{x}$ & $9.299 \times 10^{-6}$ & 0.013 & $\mathrm{x}$ & 0.039 & $5.943 \times 10^{-5}$ & $x$ & 0.010 & 0.822 & $x$ & 0.002 & 0.002 \\
\hline 6 & $x$ & X & $7.048 \times 10^{-5}$ & $x$ & $x$ & $3.838 \times 10^{-5}$ & $x$ & $\mathrm{x}$ & 0.001 & $x$ & $\mathrm{x}$ & 0.769 \\
\hline Kangoo & 3 & 6 & 9 & 3 & 6 & 9 & 3 & 6 & 9 & 3 & 6 & 9 \\
\hline 0 & $4.63 \times 10^{-5}$ & $6.21 \times 10^{-5}$ & 0.000126 & $1.82 \times 10^{-7}$ & $3.82 \times 10^{-8}$ & $3.78 \times 10^{-7}$ & 0.000128 & 0.000291 & 0.000156 & $4.32 \times 10^{-5}$ & 0.000197 & 0.001687 \\
\hline 3 & $\mathrm{x}$ & 0.139483 & 0.000224 & $\mathrm{x}$ & $1.58 \times 10^{-6}$ & $3.01 \times 10^{-6}$ & $\mathrm{x}$ & 0,002167 & 0.96516 & $\mathrm{x}$ & 0.008952 & 0.000151 \\
\hline 6 & $x$ & $\mathrm{x}$ & 0.000799 & $\mathrm{x}$ & $\mathrm{x}$ & $6.74 \times 10^{-5}$ & $x$ & $\mathrm{x}$ & 0.003795 & $\mathrm{x}$ & $\mathrm{x}$ & 0.001856 \\
\hline Wintmalt & 3 & 6 & 9 & 3 & 6 & 9 & 3 & 6 & 9 & 3 & 6 & 9 \\
\hline 0 & 0.001012 & 0.000878 & 0.001049 & $8.57 \times 10^{-7}$ & $6.75 \times 10^{-7}$ & $1.31 \times 10^{-7}$ & 0.001708 & 0.024547 & 0.033331 & $5.07 \times 10^{-6}$ & 0.000102 & $2.42 \times 10^{-5}$ \\
\hline 3 & $x$ & 0.09119 & $4.81 \times 10^{-5}$ & $x$ & 0.138831 & $1.97 \times 10^{-5}$ & $\mathrm{x}$ & 1 & 0.131031 & $x$ & 0.226106 & 0.126122 \\
\hline 6 & $x$ & $\mathrm{x}$ & $1.79 \times 10^{-5}$ & $x$ & $\mathrm{x}$ & $2.63 \times 10^{-5}$ & $x$ & $x$ & 0.306838 & $x$ & $\mathrm{x}$ & 1 \\
\hline \multicolumn{13}{|c|}{ Floor warehouse } \\
\hline Laudis & 3 & 6 & 9 & 3 & 6 & 9 & 3 & 6 & 9 & 3 & 6 & 9 \\
\hline 0 & $3.38 \times 10^{-5}$ & $7.42-06$ & $2.43 \times 10^{-5}$ & 0.001055 & $6.8 \times 10^{-5}$ & $1.56 \times 10^{-5}$ & $1.08 \times 10^{-6}$ & $4.6 \times 10^{-6}$ & $2.09 \times 10^{-6}$ & $3.1 \times 10^{-5}$ & 0.115177 & $1.03 \times 10^{-5}$ \\
\hline 3 & $x$ & 0.003418 & 0.09487 & $\mathrm{x}$ & $6 \times 10^{-5}$ & $4.4 \times 10^{-6}$ & $x$ & 1 & 0.948781 & $x$ & 0.000835 & 0.00019 \\
\hline 0 & $8.77 \times 10^{-5}$ & $4.12 \times 10^{-5}$ & 0.00015 & $9.76 \times 10^{-7}$ & $1.29 \times 10^{-6}$ & $7.35 \times 10^{-7}$ & $1.08 \times 10^{-6}$ & $4.6 \times 10^{-6}$ & $2.09 \times 10^{-6}$ & $3.25 \times 10^{-5}$ & 0.104222 & 0.002018 \\
\hline 3 & $\mathrm{x}$ & 0.945216 & 0.025161 & $\mathrm{x}$ & 0.000221 & $3.38 \times 10^{-5}$ & $\mathrm{x}$ & 1 & 0.948781 & $x$ & 0.000807 & $2.04 \times 10^{-6}$ \\
\hline 6 & $x$ & $\mathrm{x}$ & 0.008236 & $x$ & $\mathrm{x}$ & 0.002226 & $x$ & $x$ & 0.962091 & $x$ & $\mathrm{x}$ & 0.003044 \\
\hline Wintmalt & 3 & 6 & 9 & 3 & 6 & 9 & 3 & 6 & 9 & 3 & 6 & 9 \\
\hline 0 & 0.006044 & 0.001736 & 0.028045 & $3.3 \times 10^{-7}$ & $1.87 \times 10^{-7}$ & $8.93 \times 10^{-7}$ & 0.301257 & 0.272039 & 0.003851 & 0.000255 & 0.026285 & 0.000165 \\
\hline 3 & $x$ & 0.046225 & 0.089009 & $x$ & 0.010389 & 0.000171 & $\mathrm{x}$ & 0.902702 & 0.002773 & $\mathrm{x}$ & 0.023257 & 0.061123 \\
\hline 6 & $\mathrm{x}$ & $\mathrm{x}$ & 0.00819 & $\mathrm{x}$ & $x$ & $7.11 \times 10^{-5}$ & $\mathrm{x}$ & $\mathrm{x}$ & 0.002924 & $\mathrm{x}$ & $\mathrm{x}$ & 0.005776 \\
\hline
\end{tabular}

Legend: TPC—-total plate count of microorganisms, Coli—coliform bacteria, LAB—lactic acid bacteria, Spor—sporulating bacteria, 0—0. month; 3—3. month; 6—6. month; 9—9. Month. 


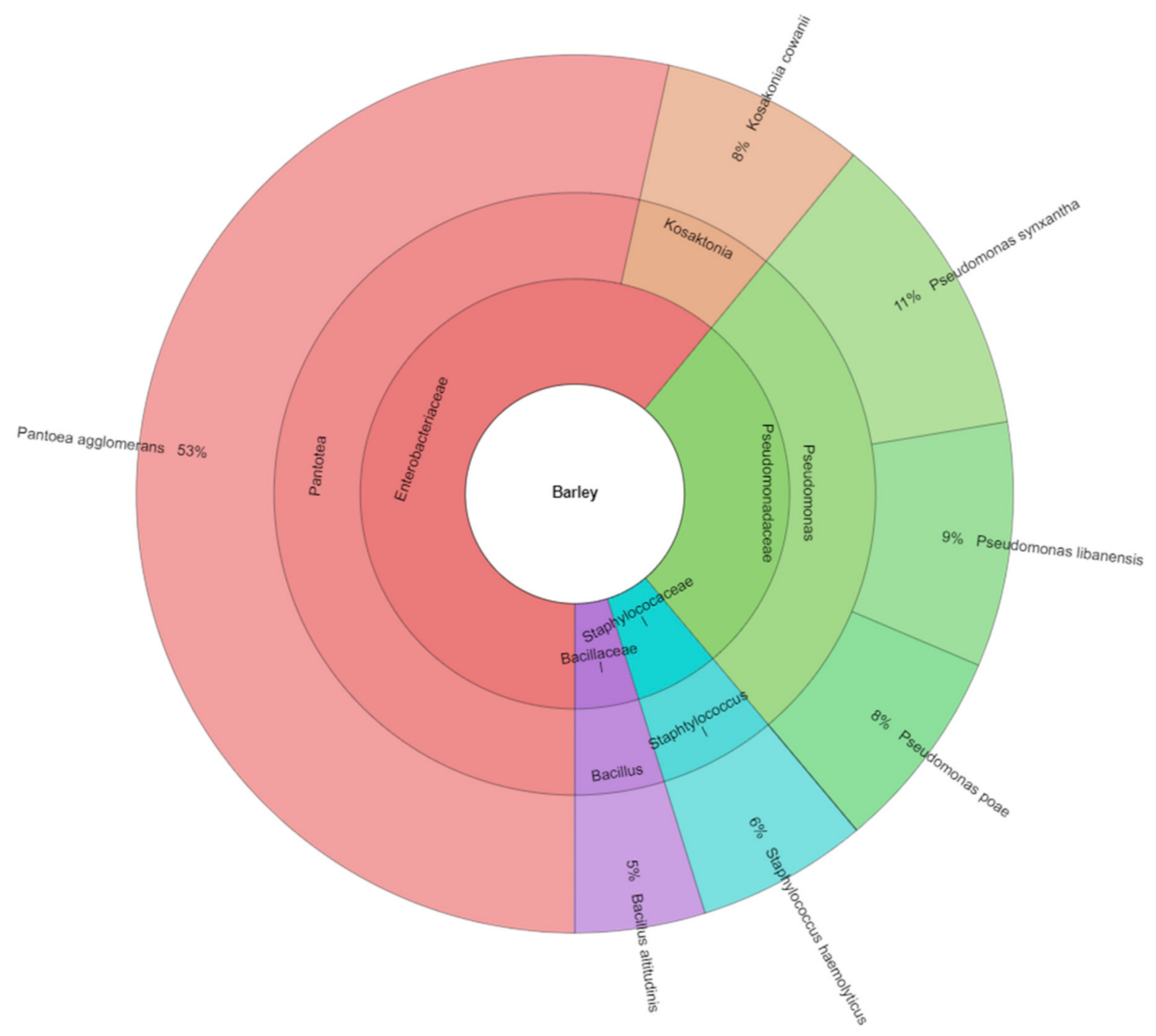

Figure 1. Krona of bacterial community isolated from barley.

Apart from the growth of microorganisms on the grain in the field and dry-stored barley (prior to malting), growth occurs during malting and malt storage [22]. Poor quality malt, often associated with high concentrations of microorganisms on barley, can impact many aspects of beer quality, be it positive or negative. The total microbial load on malt is comparable with that in barley although the composition is different [11]. The bacterial load can increase as much as 600 times during malting. Therefore, the viable bacterial load on malt is reported to be anything from 20 times higher to less than one-half of the original level in barley [23].

The results of basic chemical malt analyses are in Table 5 and microbiological malt analyses are in Table 6. It had been observed that the microbial load in malt was much higher than in barley which had the lowest microbial counts. The composition of microorganisms was also changed dependent on time and type of storage. The samples of malt prepared from longer time stored barley had a higher content of coliform bacteria, especially from stored barley in the floor warehouse, slightly increased sporulating bacteria, especially from silo, as well as slightly increased total plate count. These results correspond to microbial changes in dried and stored barley grain. The number of LAB in malt was reduced by the gradual storage of barley-like in barley. The highest amount of LAB was recorded in the malt of the Laudis barley variety. 
Table 5. Malt basic chemical parameters.

\begin{tabular}{|c|c|c|c|c|c|}
\hline $\begin{array}{l}\text { Time of } \\
\text { Storage }\end{array}$ & Varieties & $\begin{array}{c}\text { Moisture } \\
\text { Content [\%] }\end{array}$ & $\begin{array}{c}\text { Protein } \\
\text { Content [\%] }\end{array}$ & $\begin{array}{c}\text { Extract } \\
\text { Content }[\%]\end{array}$ & Friability [\%] \\
\hline \multirow{3}{*}{0.} & Laudis & 4.82 & 10.50 & 81.19 & 83.6 \\
\hline & Kangoo & 4.70 & 11.14 & 80.24 & 85.2 \\
\hline & Wintmalt & 5.28 & 9.9 & 80.8 & 83.8 \\
\hline \multicolumn{6}{|c|}{ Grain silo } \\
\hline \multirow{3}{*}{ 3. months } & Laudis & 3.78 & 10.69 & 82.63 & 86.1 \\
\hline & Kangoo & 3.82 & 10.93 & 82.39 & 91.6 \\
\hline & Wintmalt & 4.37 & 10.18 & 81.44 & 85.5 \\
\hline \multirow{3}{*}{ 6. months } & Laudis & 4.29 & 10.72 & 82.24 & 88.0 \\
\hline & Kangoo & 4.33 & 10.84 & 81.72 & 88.9 \\
\hline & Wintmalt & 4.85 & 10.02 & 82.23 & 86.5 \\
\hline \multirow{3}{*}{ 9. months } & Laudis & 4.15 & 10.82 & 81.97 & 87.5 \\
\hline & Kangoo & 4.50 & 10.88 & 82.01 & 89.2 \\
\hline & Wintmalt & 4.66 & 10.05 & 82.35 & 87.2 \\
\hline \multicolumn{6}{|c|}{ Floor warehouse } \\
\hline \multirow{3}{*}{ 3. months } & Laudis & 3.96 & 10.75 & 83.12 & 87.9 \\
\hline & Kangoo & 4.02 & 10.84 & 82.07 & 91.7 \\
\hline & Wintmalt & 4.61 & 10.39 & 82.32 & 86.9 \\
\hline \multirow{3}{*}{ 6. months } & Laudis & 3.75 & 10.91 & 83.02 & 87.9 \\
\hline & Kangoo & 3.88 & 10.98 & 81.89 & 90.7 \\
\hline & Wintmalt & 4.52 & 9.88 & 82.64 & 89.3 \\
\hline \multirow{3}{*}{ 9. months } & Laudis & 3.83 & 10.75 & 82.90 & 88.5 \\
\hline & Kangoo & 3.98 & 11.02 & 81.97 & 90.5 \\
\hline & Wintmalt & 4.72 & 9.90 & 82.53 & 89.0 \\
\hline
\end{tabular}

Table 6. Quantitative and qualitative composition of various groups of microorganisms in malt depending on the time and type of storage of the three varieties of barley.

\begin{tabular}{|c|c|c|c|c|c|c|}
\hline $\begin{array}{l}\text { Time of } \\
\text { Storage }\end{array}$ & Varieties & $\begin{array}{c}\text { TPC } \\
\log \mathrm{cfu} / \mathrm{g}\end{array}$ & $\begin{array}{c}\text { Coli } \\
\log \mathrm{cfu} / \mathrm{g}\end{array}$ & $\begin{array}{c}\text { LAB } \\
\log \mathrm{cfu} / \mathrm{g}\end{array}$ & $\begin{array}{c}\text { Spor } \\
\log \mathrm{cfu} / \mathrm{g}\end{array}$ & Species \\
\hline \multirow{3}{*}{0.} & Laudis & $7.00 \pm 0.01$ & $4.70 \pm 0.13$ & $5.00 \pm 0.06$ & $1.36 \pm 0.08$ & \multirow{3}{*}{$\begin{array}{c}\text { Bacillus cereus } \\
\text { Enterococcus mundtii } \\
\text { Pseudomonas } \\
\text { oryzihabitans }\end{array}$} \\
\hline & Kangoo & $6.98 \pm 0.15$ & $3.97 \pm 0.15$ & $3.56 \pm 0.03$ & $1.00 \pm 0.11$ & \\
\hline & Wintmalt & $7.08 \pm 0.09$ & $2.70 \pm 0.14$ & $2.91 \pm 0.14$ & $1.11 \pm 0.12$ & \\
\hline \multicolumn{7}{|c|}{ Grain/cereal silo } \\
\hline \multirow{3}{*}{ 3. months } & Laudis & $7.48 \pm 0.08$ & $4.97 \pm 0.08$ & $4.38 \pm 0.09$ & $2.30 \pm 0.13$ & \multirow{3}{*}{$\begin{array}{c}\text { Staphylococcus warneri, } \\
\text { Enterobacter cloacae, } \\
\text { E. ludwigii } \\
\text { Enterococcus mundtii } \\
\text { Pseudomonas } \\
\text { oryzihabitans, } \\
\text { Ps. orientalis }\end{array}$} \\
\hline & Kangoo & $6.92 \pm 0.07$ & $3.15 \pm 0.06$ & $2.65 \pm 0.04$ & $2.51 \pm 0.07$ & \\
\hline & Wintmalt & $7.32 \pm 0.05$ & $3.51 \pm 0.08$ & $4.11 \pm 0.09$ & $4.11 \pm 0.05$ & \\
\hline \multirow{3}{*}{ 6. months } & Laudis & $7.48 \pm 0.09$ & $5.99 \pm 0.09$ & $3.79 \pm 0.09$ & $2.49 \pm 0.08$ & \multirow{3}{*}{$\begin{array}{l}\text { Enterobacter cloacae, } \\
\text { E. asburiae, E. kobei } \\
\text { Enterococcus mundtii } \\
\text { Pantoea agglomerans }\end{array}$} \\
\hline & Kangoo & $7.08 \pm 0.05$ & $5.34 \pm 0.12$ & $2.18 \pm 0.07$ & $2.72 \pm 0.08$ & \\
\hline & Wintmalt & $7.48 \pm 0.12$ & $5.76 \pm 0.12$ & $3.15 \pm 0.13$ & $2.45 \pm 0.13$ & \\
\hline \multirow{3}{*}{ 9. months } & Laudis & $7.73 \pm 0.15$ & $7.08 \pm 0.06$ & $4.91 \pm 0.17$ & $3.00 \pm 0.10$ & \multirow{3}{*}{$\begin{array}{l}\text { Enterobacter cloacae, } \\
\text { E. asburiae, E. kobei } \\
\text { Pantoea agglomerans } \\
\text { Pantoea agglomerans }\end{array}$} \\
\hline & Kangoo & $7.08 \pm 0.14$ & $6.28 \pm 0.14$ & $2.65 \pm 0.16$ & $2.85 \pm 0.13$ & \\
\hline & Wintmalt & $7.30 \pm 0.09$ & $7.15 \pm 0.06$ & $3.73 \pm 0.15$ & $3.11 \pm 0.08$ & \\
\hline
\end{tabular}


Table 6. Cont.

\begin{tabular}{|c|c|c|c|c|c|c|}
\hline $\begin{array}{l}\text { Time of } \\
\text { Storage }\end{array}$ & Varieties & $\begin{array}{c}\text { TPC } \\
\log \mathrm{cfu} / \mathrm{g}\end{array}$ & $\begin{array}{c}\text { Coli } \\
\log \mathrm{cfu} / \mathrm{g}\end{array}$ & $\begin{array}{c}\text { LAB } \\
\log \mathrm{cfu} / \mathrm{g}\end{array}$ & $\begin{array}{c}\text { Spor } \\
\log \mathrm{cfu} / \mathrm{g}\end{array}$ & Species \\
\hline \multicolumn{7}{|c|}{ Floor warehouse } \\
\hline \multirow{3}{*}{ 3. months } & Laudis & $7.36 \pm 0.05$ & $5.28 \pm 0.09$ & $5.38 \pm 0.14$ & $2.15 \pm 0.06$ & \multirow{3}{*}{$\begin{array}{c}\text { Erwinia persicina } \\
\text { Raoultella } \\
\text { ornithinolytica, } \\
\text { Acinetobacter pittii, } \\
\text { Klebsiella oxytoca } \\
\text { Pantoea agglomerans }\end{array}$} \\
\hline & Kangoo & $7.20 \pm 0.09$ & $4.40 \pm 0.14$ & $3.67 \pm 0.16$ & $1.51 \pm 0.04$ & \\
\hline & Wintmalt & $7.26 \pm 0.08$ & $3.76 \pm 0.07$ & $3.67 \pm 0.06$ & $1.51 \pm 0.06$ & \\
\hline \multirow{3}{*}{ 6. months } & Laudis & $7.58 \pm 0.10$ & $6.51 \pm 0.06$ & $5.08 \pm 0.04$ & $2.04 \pm 0.14$ & \multirow{3}{*}{$\begin{array}{l}\text { Pantoea agglomerans } \\
\text { Pantoea agglomerans } \\
\text { Pantoea agglomerans }\end{array}$} \\
\hline & Kangoo & $7.28 \pm 0.07$ & $5.86 \pm 0.10$ & $1.00 \pm 0.08$ & $1.36 \pm 0.10$ & \\
\hline & Wintmalt & $7.28 \pm 0.06$ & $6.18 \pm 0.03$ & $1.00 \pm 0.03$ & $1.74 \pm 0.04$ & \\
\hline \multirow{3}{*}{ 9. months } & Laudis & $8.15 \pm 0.11$ & $7.30 \pm 0.08$ & $4.58 \pm 0.11$ & $3.15 \pm 0.03$ & \multirow{3}{*}{$\begin{array}{l}\text { Pantoea agglomerans } \\
\text { Leclercia adecarboxylata } \\
\text { Pantoea agglomerans, } \\
\text { Leclercia adecarboxylata }\end{array}$} \\
\hline & Kangoo & $7.28 \pm 0.15$ & $6.78 \pm 0.11$ & $2.88 \pm 0.06$ & $1.76 \pm 0.07$ & \\
\hline & Wintmalt & $7.56 \pm 0.08$ & $7.15 \pm 0.01$ & $2.70 \pm 0.09$ & $2.32 \pm 0.06$ & \\
\hline
\end{tabular}

Legend: TPC—-total plate count of microorganisms, Coli-coliform bacteria, LAB-lactic acid bacteria, Spor-sporulating bacteria.

The following bacteria were isolated from malts: Acinetobacter pittii, Bacillus cereus, Enterobacter asburiae, E. cloacae, E. kobei, E. ludwigii, Enterococcus mundtii, Erwinia persicina, Klebsiella oxytoca, Leclercia adecarboxylata, Pantoea agglomerans, Pseudomonas orientalis, Ps. oryzihabitans, Raoultella ornithinolytica, and Staphylococcus warneri. A total of 822 isolates from malt were identified (Figure 2). These bacteria species were from 11 genera and six families. Van Nierop et al. [22] described that the increase in bacterial counts was dominated by Pseudomonas, with a substantial increase in the lactic acid bacteria. In barley, we isolated three species of genera Pseudomonas: Pseudomonas libanensis, Pseudomonas poae, Pseudomonas synxantha, and in malt, two Pseudomonas oryzihabitans and Pseudomonas orientalis.

When analyzing the statistical differences among microorganisms found in malt/grain depending on the time of storage (Table 7), total plate count of microorganisms (TPC) was in most cases statistically insignificant at the level of $p<0.05$ for all of the three analyzed varieties, and they had mostly the same pattern with the only exceptions, where Laudis had a significant difference at all the three times compared to the zero month. When analyzing the other malt/grains and malt/floor warehouse, the results were more variable.

O'Sullivan et al. [20] reported that $1.6-20 \%$ of the viable heterotrophic bacteria in stored malting barley were members of the Enterobacteriaceae, with these Gram-negative bacteria consisting of the microbiota of 123 barley species typically associated with plant material, including E. nigrificans, Enterobacter agglomerans, and Serratia odorifera. Pseudomonas spp., mainly Pseudomonas fluorescens, Pseudomonas cepacia, and Pseudomonas putida, accounted for 1.6-3.9\% of the viable total, lactic acid bacteria, including Leuconostoc mesenteroides, Lacotococcus lactis, Lactobacillus coprophilus, and $L b$. plantarum, comprised $<0.01 \%$. Lactic acid bacteria are also present as part of the natural barley microbiota and persist during malting and mashing. They play a positive role in the beer-manufacturing process by contributing to wort bioacidification [24]. Lactic acid bacteria, especially the genera Lactobacillus and Pediococcus, are considered the most noxious [14]. According to previous estimates, they have been responsible for 60-90\% of cases of microbial spoilage of beer in Europe in the period 1980-2002 [25,26]. Undesirably, primary contamination by lactic acid bacteria can severely damage the sensory properties of beer by generating undesirable sensory substances already during beer production, and secondary (post-pasteurization) contamination, which can damage the final product by causing turbidity and adversely affecting its taste and smell [27]. 
Table 7. $p$-values among analyzed malt depending on the time and type of storage of the three varieties of barley $(p<0.05)$.

\begin{tabular}{|c|c|c|c|c|c|c|c|c|c|c|c|c|}
\hline $\begin{array}{l}\text { Variety/Microorganism } \\
\text { Groups }\end{array}$ & & TPC & & & COLI & & & LAB & & & Spor & \\
\hline \multicolumn{13}{|c|}{ Grain } \\
\hline Laudis & 3 & 6 & 9 & 3 & 6 & 9 & 3 & 6 & 9 & 3 & 6 & 9 \\
\hline 0 & 0.000502 & 0.000682 & 0.001033 & 0.040016 & 0.000153 & $8.91 \times 10^{-6}$ & 0.000514 & $4.16 \times 10^{-5}$ & 0.424663 & 0.000456 & $6.66 \times 10^{-5}$ & $2.42 \times 10^{-5}$ \\
\hline 3 & $\mathrm{x}$ & 1 & 0.061125 & $\mathrm{x}$ & 0.000138 & $3.62 \times 10^{-6}$ & $\mathrm{x}$ & 0.001419 & 0.00933 & $\mathrm{x}$ & 0.10536 & 0.001862 \\
\hline 6 & $x$ & $\mathrm{x}$ & 0.064389 & $x$ & $\mathrm{x}$ & $7.11 \times 10^{-5}$ & $x$ & $\mathrm{x}$ & 0.000601 & $x$ & $\mathrm{x}$ & 0.002295 \\
\hline Kangoo & 3 & 6 & 9 & 3 & 6 & 9 & 3 & 6 & 9 & 3 & 6 & 9 \\
\hline 0 & 0.544688 & 0.329678 & 0.434449 & 0.00092 & 0.000251 & $4.29 \times 10^{-5}$ & $7.86 \times 10^{-6}$ & $7.16 \times 10^{-6}$ & 0.000609 & $4.29 \times 10^{-5}$ & $2.77 \times 10^{-5}$ & $5.16 \times 10^{-5}$ \\
\hline 3 & $\mathrm{x}$ & 0.037567 & 0.151835 & $\mathrm{x}$ & $9.4 \times 10^{-6}$ & $4.03 \times 10^{-6}$ & $\mathrm{x}$ & 0.000569 & 0.973323 & $\mathrm{x}$ & 0.030593 & 0.018556 \\
\hline 6 & $x$ & $\mathrm{x}$ & 0,971782 & $\mathrm{x}$ & x & 0.000975 & $x$ & $\mathrm{x}$ & 0.009395 & $x$ & $\mathrm{x}$ & 0.218189 \\
\hline Wintmalt & 3 & 6 & 9 & 3 & 6 & 9 & 3 & 6 & 9 & 3 & 6 & 9 \\
\hline 0 & 0.016937 & 0.009634 & 0.041394 & 0.001107 & $9.85 \times 10^{-6}$ & $1.13 \times 10^{-6}$ & 0.000281 & 0.097998 & 0.002628 & $2.1 \times 10^{-6}$ & 0.000189 & $1.48 \times 10^{-5}$ \\
\hline 3 & $\mathrm{x}$ & 0.09859 & 0.759835 & $\mathrm{x}$ & $1.11 \times 10^{-5}$ & $4.06 \times 10^{-7}$ & $\mathrm{x}$ & 0.000436 & 0.020754 & $\mathrm{x}$ & $3.52 \times 10^{-5}$ & $4.72 \times 10^{-5}$ \\
\hline 6 & $x$ & $\mathrm{x}$ & 0.105096 & $x$ & $\mathrm{x}$ & $6.14 \times 10^{-5}$ & $\mathrm{x}$ & $\mathrm{x}$ & 0.007229 & $x$ & $\mathrm{x}$ & 0.001659 \\
\hline \multicolumn{13}{|c|}{ Floor warehouse } \\
\hline Laudis & 3 & 6 & 9 & 3 & 6 & 9 & 3 & 6 & 9 & 3 & 6 & 9 \\
\hline 0 & 0.00027 & 0.000496 & $5.03 \times 10^{-5}$ & 0.003126 & $2.54 \times 10^{-5}$ & $8.38 \times 10^{-6}$ & 0.011918 & 0.130162 & 0.003555 & 0.000165 & 0.001825 & $3.41 \times 10^{-6}$ \\
\hline 3 & $\mathrm{x}$ & 0.02561 & 0.000333 & $\mathrm{x}$ & $3.39 \times 10^{-5}$ & $8.45 \times 10^{-6}$ & $\mathrm{x}$ & 0.021626 & 0.001358 & $\mathrm{x}$ & 0.29307 & $1.44 \times 10^{-5}$ \\
\hline 6 & $x$ & $\mathrm{x}$ & 0.002505 & $\mathrm{x}$ & $\mathrm{x}$ & 0.000177 & $x$ & $\mathrm{x}$ & 0.001566 & $x$ & $\mathrm{x}$ & 0.000183 \\
\hline Kangoo & 3 & 6 & 9 & 3 & 6 & 9 & 3 & 6 & 9 & 3 & 6 & 9 \\
\hline 0 & 0.017181 & 0.001915 & 0.034695 & 0.052115 & 0.000276 & $2.8 \times 10^{-5}$ & 0.000171 & $5.67 \times 10^{-8}$ & $1.62 \times 10^{-6}$ & 0.040731 & 0.109993 & 0.00279 \\
\hline 3 & $\mathrm{x}$ & 0.256915 & 0.48693 & $x$ & 0.000128 & $1.87 \times 10^{-5}$ & $\mathrm{x}$ & $1.01 \times 10^{-5}$ & 0.001403 & $\mathrm{x}$ & 1 & 0.005281 \\
\hline 6 & $x$ & $\mathrm{x}$ & 0.947414 & $x$ & $\mathrm{x}$ & 0.000422 & $\mathrm{x}$ & $\mathrm{x}$ & $1.73 \times 10^{-6}$ & $x$ & $x$ & 0.007703 \\
\hline Wintmalt & 3 & 6 & 9 & 3 & 6 & 9 & 3 & 6 & 9 & 3 & 6 & 9 \\
\hline 0 & 0.003925 & 0.00112 & 0.000239 & 0.000394 & $4.58 \times 10^{-5}$ & $1.35 \times 10^{-5}$ & $1.01 \times 10^{-5}$ & $3.62 \times 10^{-8}$ & $2.62 \times 10^{-6}$ & 0.053766 & 0.001849 & $7.66 \times 10^{-5}$ \\
\hline 3 & $x$ & 0.73302 & 0.008581 & $x$ & $7.94 \times 10^{-7}$ & $1.16 \times 10^{-6}$ & $x$ & $2.77 \times 10^{-7}$ & $9.53 \times 10^{-5}$ & $x$ & 0.005367 & $7.6 \times 10^{-5}$ \\
\hline 6 & $\mathrm{x}$ & $\mathrm{x}$ & 0.007432 & $\mathrm{x}$ & $x$ & $9.2 \times 10^{-5}$ & $\mathrm{x}$ & $\mathrm{x}$ & $5.33 \times 10^{-6}$ & $\mathrm{x}$ & $x$ & 0.000158 \\
\hline
\end{tabular}

Legend: TPC—total plate count of microorganisms, Coli-coliform bacteria, LAB-lactic acid bacteria, Spor-sporulating bacteria, 0—0. month; 3-3. month; 6-6. month; 9—9. Month. 


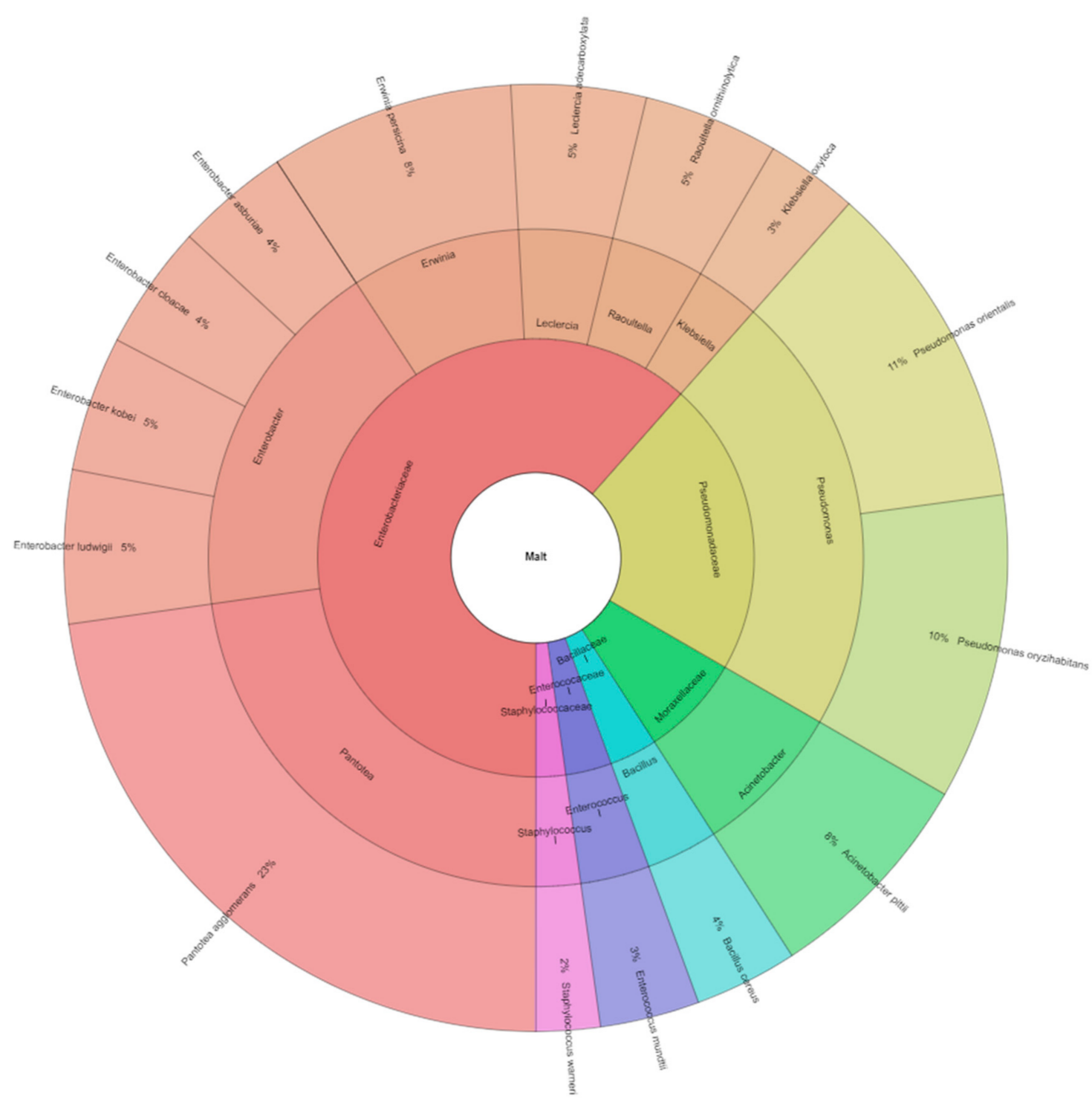

Figure 2. Krona of bacterial community isolated from malt.

Bacteria of the genus Bacillus are often detected in brewing operations, but they rank among less hazardous contaminants. They are not able to survive in the vegetative form in beer and spoil it. Spores of Bacillus bacteria are present especially in malt and grain adjuncts. They are able to survive wort boiling; however, in the following phases they are not able to germinate because of their sensitivity to bitter hop substances and low $\mathrm{pH}$ of fermenting wort and finished beer [28]. Some Bacillus species may cause food poisoning. The most common cause of food poisoning is Bacillus cereus, which produces toxins in the course of growth on polysaccharide substrates. The food poisoning occurs when a consumer consumes food containing $10^{7}$ cells per $g$ of food [29]. Scientific studies have also demonstrated the ability of Bacillus cereus and Bacillus licheniformis to grow in beer due to the presence of the HorA gene $[9,30]$. In this case, Bacillus cereus could pose increased risk due to its ability to produce a variety of toxins and enzymes [31].

From the point of view of microbiological control in the brewing laboratory, particularly important genera in Enterobacterales order are Shimwellia, Obesumbacterium, Rahnella, Citrobacter, Klebsiella, Raoultella, Serratia, and Enterobacter. Pathogenic species, including E. coli, Shigella, Salmonella, have not been found in the brewing industry [32]. Klebsiella oxytoca has been reported in the brewery environment. In the fermented wort, Klebsiella species produce phenolic aroma and taste due to the formation of 4-vinylguaiacol. A considerable amount of dimethylsulfide passes into the finished beer from wort 
contaminated with klebsiellas [32]. Bacteria of Raoultella genus were originally included in the Klebsiella genus. Raoultella terrigena (formerly Klebsiella terrigena) has been reported in the brewery environment. The presence of Raoultella terrigena in the fermented wort, as well as Klebsiella oxytoca, is associated with beer damage by a high concentration of 4-vinylguaiacol and dimethylsulfide. In addition, Raoultella terrigena produces high concentration of acetoine and 2,3-butanediol [33,34]. Together with Klebsiella oxytoca, we isolated Raoultella ornithinolytica from our malt sample Kangoo in floor warehouse. The genus Enterobacter can grow in the wort and at the beginning of the main fermentation. Enterobacter cloacae is harmful due to the production of phenolic substances and dimethylsulfide at the beginning of the main fermentation, and due to the passage of substances into finished beer [21]. Except for Enterobacter cloacae, we isolated Enterobacter asburiae, Enterobacter ludwigii and Enterobacter kobei from malt Laudis from silo.

\section{Conclusions}

Trials carried out proved significant impact of the time of barley storage and the type of barley storage. The type of barley storage had more important impact on some microorganisms, other microorganisms were influenced primarily by the time of barley storage. The storage of barley had an influence on the coliform bacteria and did not have any influence on the lactic acid bacteria, sporulating bacteria, and the total plate counts. The number of coliform bacteria was slightly higher in grains stored in floor warehouses than in silos for all barley varieties. We observed it similarly in malt. The composition of microorganisms was changed and was dependent on the time of storage, especially on the number of coliform bacteria which gradually increased with the growing months in storage. The number of lactic acid bacteria in barley grains with the growing months in storage and malt produced from them decreased slightly and the content of sporulating bacteria in all samples fluctuated slightly.

The most frequent bacteria in barley was Pantoea agglomerans, and in malt composition of bacteria was more varied with the largest proportion of coliform bacteria of the family Enterobacteriaceae.

Author Contributions: Conceptualization, S.F., T.K., Š.D. and M.K.; Investigation, S.F., T.K. and M.K.; Methodology, S.F., T.K., Š.D. and M.K.; Supervision, S.F., P.Ł.K. and M.K.; Writing-original draft, S.F., P.Ł.K., T.K., Š.D. and M.K. All authors have read and agreed to the published version of the manuscript.

Funding: This work has been supported by the grants of the VEGA no. 1/0180/20.

Acknowledgments: The Paper was supported by the project. The research leading to these results has received funding from the European Community under project no. 26220220180: Building Research Centre "AgroBioTech".

Conflicts of Interest: The authors declare no conflict of interest. The funders had no role in the design of the study; in the collection, analyses, or interpretation of data; in the writing of the manuscript, or in the decision to publish the results.

\section{References}

1. Noots, I.; Delcour, J.A.; Michiels, C.W. From Field Barley to Malt: Detection and Specification of Microbial Activity for Quality Aspects. Crit. Rev. Microbiol. 1999, 25, 121-153. [CrossRef]

2. Angelino, S.; Bol, J. Impact of microflora during storage and malting on malt properties. In Raw Materials and Sweet Wort Production, Proceedings of the Jean De Clerck Chair IV, Leuven, Belgium, 23-27 September 1990; Jean Monnet Aditorium: Leuven, Belgium, 1990; pp. 1-14.

3. Flannigan, B. The microbiota of barley and malt. In Brewing Microbiology; Springer US: Boston, MA, USA, 2003; pp. 113-180.

4. Laitila, A.; Sarlin, T.; Raulio, M.; Wilhelmson, A.; Kotaviita, E.; Huttunen, T.; Juvonen, R. Yeasts in malting, with special emphasis on Wickerhamomyces anomalus (synonym Pichia anomala). Antonie Van Leeuwenhoek 2011, 99, 75-84. [CrossRef]

5. Doran, P.J.; Briggs, D.E. Microbes and grain germination. J. Inst. Brew. 1993, 99, 165-170. [CrossRef]

6. Oliveira, P.M.; Zannini, E.; Arendt, E.K. Cereal fungal infection, mycotoxins, and lactic acid bacteria mediated bioprotection: From crop farming to cereal products. Food Microbiol. 2014, 37, 78-95. [CrossRef] [PubMed] 
7. Belokurova, E.; Pankina, I.; Sevastyanova, A.; Asfondyarova, I.; Katkova, N. The influence of barley weed impurities on the microbiological quality indicators. E3S Web Conf. 2020, 161, 01072. [CrossRef]

8. Justé, A.; Malfliet, S.; Waud, M.; Crauwels, S.; De Cooman, L.; Aerts, G.; Marsh, T.L.; Ruyters, S.; Willems, K.; Busschaert, P.; et al. Bacterial community dynamics during industrial malting, with an emphasis on lactic acid bacteria. Food Microbiol. 2014, 39, 39-46. [CrossRef] [PubMed]

9. Bokulich, N.A.; Bamforth, C.W. The Microbiology of Malting and Brewing. Microbiol. Mol. Biol. Rev. 2013, 77, 157-172. [CrossRef] [PubMed]

10. Briggs, D.E.; McGuinness, G. Microbes on barley grains. J. Inst. Brew. 1993, 99, 249-255. [CrossRef]

11. Petters, H.I.; Flannigan, B.; Austin, B. Quantitative and qualitative studies of the microflora of barley malt production. J. Appl. Bacteriol. 1988, 65, 279-297. [CrossRef]

12. Luarasi, L.; Troja, R.; Pinguli, L. Microbiological safety and quality evaluation of the raw materials used in beer production. J. Hyg. Eng. Des. 2016, 16, 28-31.

13. Justé, A.; Malfliet, S.; Lenaerts, M.; De Cooman, L.; Aerts, G.; Willems, K.A.; Lievens, B. Microflora during malting of barley: Overview and impact on malt quality. Brew. Sci. 2011, 64, 22-31.

14. Vaughan, A.; O'Sullivan, T.; Sinderen, D. Enhancing the Microbiological Stability of Malt and Beer-A Review. J. Inst. Brew. 2005, 111, 355-371. [CrossRef]

15. Dalié, D.K.D.; Deschamps, A.M.; Richard-Forget, F. Lactic acid bacteria-Potential for control of mould growth and mycotoxins: A review. Food Control 2010, 21, 370-380. [CrossRef]

16. Matoulková, D.; Vontrobová, E.; Brožová, M.; Kubizniaková, P. Microbiology of brewery production-bacteria of the order Enterobacterales. Kvas. Prum. 2018, 64, 161-166. [CrossRef]

17. Buňka, F.; Budinský, P.; Čechová, M.; Drienovský, V.; Pachlová, V.; Matoulková, D.; Kubáň, V.; Buňková, L. Content of biogenic amines and polyamines in beers from the Czech Republic. J. Inst. Brew. 2012, 118, 213-216. [CrossRef]

18. EBC. Analysis Committee. In Analytica-EBC; Fachverlag, Hans Carl: Nürnberg, Germany, 2010; ISBN 978-3-418-00759-5.

19. Kačániová, M.; Mellen, M.; Vukovic, N.L.; Kluz, M.; Puchalski, C.; Haščík, P.; Kunová, S. Combined Effect of Vacuum Packaging, Fennel and Savory Essential Oil Treatment on the Quality of Chicken Thighs. Microorganisms 2019, 7, 134. [CrossRef]

20. O'Sullivan, T.F.; Walsh, Y.; O'Mahony, A.; Fitzgerald, G.F.; Sinderen, D. A Comparative Study of Malthouse and Brewhouse Microflora. J. Inst. Brew. 1999, 105, 55-61. [CrossRef]

21. Priest, F.G.; Campbell, I. Brewing Microbiology; Springer: Boston, MA, USA, 2003; ISBN 978-1-4613-4858-0.

22. Van Nierop, S.N.E.; Rautenbach, M.; Axcell, B.C.; Cantrell, I.C. The impact of microorganisms on barley and malt quality-A review. J. Am. Soc. Brew. Chem. 2006, 64, 69-78. [CrossRef]

23. Douglas, P.E.; Flannigan, B. A microbiological evaluation of barley malt production. J. Inst. Brew. 1988, 94, 85-88. [CrossRef]

24. Lewis, D. Biological mash and wort acidification. New Brew. 1998, 15, 36-45.

25. Back, W. Secondary contaminations in the filling area. Brauwelt Int. 1994, 12, 326-333.

26. Back, W. Biofilme in der Brauerei und Getrankeindustrie-15 Jahre Praxiserfahrung. Brauwelt 2003, $24,766-777$.

27. Back, W. Colour Atlas and Hand-Book of Beverage Biology; Back, W., Ed.; Verlag Hans Carl: Nürnberg, Germany, 2005; pp. 10-112.

28. Brožová, M.; Kubizniaková, P.; Matoulková, D. Brewing Microbiology-Bacteria of the Genera Bacillus, Brevibacillus and Paenibacillus and Cultivation Methods for their Detection-Part 1. Kvas. Prum. 2018, 64, 50-57. [CrossRef]

29. Logan, N.A.; De Vos, P. Bacillus. In Bergey's Manual of Systematics of Archaea and Bacteria; Whitman, W.B., Ed.; John Wiley \& Sons, Inc.: Hoboken, NJ, USA, 2015.

30. Haakensen, M.; Ziola, B. Identification of novel horA-Harbouring bacteria capable of spoiling beer. Can. J. Microbiol. 2008, 54, 321-325. [CrossRef] [PubMed]

31. Drobniewski, F.A. Bacillus cereus and related species. Clin. Microbiol. Rev. 1993, 6, 324-338. [CrossRef]

32. Van Vuuren, H.J.J.; Priest, F.G. Gram-negative brewery bacteria. In Brewing Microbiology; Springer US: Boston, MA, USA, 2003; pp. 219-245. 
33. Blomqvist, K.; Nikkola, M.; Lehtovaara, P.; Suihko, M.L.; Airaksinen, U.; Stråby, K.B.; Knowles, J.K.; Penttilä, M.E. Characterization of the genes of the 2,3-butanediol operons from Klebsiella terrigena and Enterobacter aerogenes. J. Bacteriol. 1993, 175, 1392-1404. [CrossRef]

34. Drancourt, M.; Bollet, C.; Carta, A.; Rousselier, P. Phylogenetic analyses of Klebsiella species delineate Klebsiella and Raoultella gen. nov., with description of Raoultella ornithinolytica comb. nov., Raoultella terrigena comb. nov. and Raoultella planticola comb. nov. Int. J. Syst. Evol. Microbiol. 2001, 51, 925-932. [CrossRef]

(C) 2020 by the authors. Licensee MDPI, Basel, Switzerland. This article is an open access article distributed under the terms and conditions of the Creative Commons Attribution (CC BY) license (http://creativecommons.org/licenses/by/4.0/). 